\title{
RETHINKING FAIRNESS: PRINCIPLED LEGAL REALISM AND FEDERAL JURISDICTION
}

\author{
Aviam Solfer*
}

In celebrating Judge Jon O. Newman's three decades on the federal bench, and in reflecting particularly on the past and future of federal court jurisdiction, this symposium reminds us of elements of character, time, and skill required to perform with the "special competence normally expected of federal judges." We do so in honor of an exceptional federal judge, however, whose special qualities as a judge, author, and teacher palpably exceed normal expectations. By focusing briefly on what Judge Newman has said and done about federal jurisdiction, we can begin to discern a model for principled legal realism. This model contrasts sharply with the incurious and overly binary approach of the current Court to such matters. Yet it has important implications-specific and general-for what we ought to expect from federal judges, even if they will not approach Newman's extraordinary blending of analytic vigor, clarity, and a balanced, keenly practical sense of the implications of any judicial decision, or of no decision at all.

Each generation of law students takes too seriously, and nevertheless seeks to overturn, the dominant norms espoused by their professors. ${ }^{2}$ It seems initially paradoxical, for example, that Jon Newman, a

* Aviam Soifer teaches and has written extensively in the areas of American legal history and constitutional law at Boston College Law School, where he served as Dean from 1993-98. He clerked for Jon O. Newman in 1972-73, Newman's first full year as a federal district court judge.

Professor Soifer would like to express his great gratitude to Judge Newman, and also to Jeanne Ostapkevich and Leonard S. Spector, who made 1972-73 such an extraordinary and entertaining year. In addition, Paul Dubinsky and the staff of the Law Review deserve special appreciation and many thanks for their patience as well as their imagination in planning and implementing this symposium. Other symposium participants, other law clerks, and New York Law School helped create a most noteworthy occasion. Finally, Marlene Booth, Mary Bilder, and Ray Madoff generously read drafts with exceptional care and made their customary, extremely helpful suggestions.

1. Jon O. Newman, Restructuring Federal Jurisdiction: Proposals to Preserve the Federal Judicial System, 56 U. CH1. L.REv. 761, 766 (1989).

2. A majority of the current Justices of the United States Supreme Court went to the Harvard Law School during the salad days of Legal Process's emphasis on respect for appropriate institutional roles. Apparently five Justices actually imbibed Legal Pro- 
consummately careful judicial craftsman, studied at Yale Law School in the 1950s, when Yale was still the epicenter of what remained of legal realism. He went on to clerk for Chief Justice Earl Warren during the 1957 Term, when bitter attacks about the Court's activism emerged from the widespread, fervent Southern resistance growing out of the school desegregation decisions and began to spread around the country.

Emerging from this background, Newman developed an approach best described as principled realism. The very concept of principled legal realism seems oxymoronic. Yet Newman's words, judgments, and hard-headed proposals for substantial reform are based on two competing important insights: First, paying attention to what judges actually do reveals that " $[\mathrm{t}]$ he ordinary business of judges is to apply the law as they understand it to reach results with which they do not necessarily agree." 3 It is also important to notice, however, that "[1]egal principles, evolved to assist the orderly resolution of disputes arising across the full range of human activities, reflect the untidiness of life" and "will not remain static." It follows in judging, therefore, that "a measure of both reasoning and expression of preferences will inevitably be involved."5 Nonetheless, this approach need not degenerate into unbounded indeterminacy.

cess directly from Henry Hart and Al Sacks. Laura E. Little, Hiding with Words: Obfuscation, Avoidance, and Federal Jurisdiction Opinions, 46 UCLA L. Rev. 75, 133, n.237 (1998) (most of the sitting Justices took Hart and Sacks's legal process class at Harvard). Justice Ginsburg spent two years at Harvard (1955-57) but graduated from Columbia; Justice Scalia was at Harvard from 1957-60; Justice Kennedy from 1958-61; Justice Breyer from 1961-64; and Justice Souter from 1963-66.

Yet the current Court often rejects institutional role sensitivity-to say nothing of seeming heedless of the demands of careful reasoning, internal coherence, procedural regularity, and fairness. The Justices sometimes appear to delight in abusing the powers of both the telescope-by invoking airy abstractions about federalism-and the microscope-by simply steamrollering the nitty-gritty of the law of federal courts, administrative law, and even basic civil procedure in the name of their own authority. See generally Aviam Soifer, Courting Anarchy, 82 B.U. L. Rev. 699 (2002).

Ironic lack of correlation between dominant values in a particular law school culture and the values of an alumnus may be best demonstrated by comparing Yale Law School in the early 1970s with the positions taken by Justice Thomas. It should be obvious that, despite assumptions in legal academia about our influence on our students, this small sample underscores that lawyers and judges tend to go their own way.

3. See Jon O. Newman, Between Legal Realism and Neutral Principles: The Legitimacy of Institutional Values, 72 CAL. L. REv. 200, 204 (1984).

4. Id. at 208 .

5. Id. 
Judge Newman carefully attends to and understands specifics and thinks hard about how they relate to more general institutional issues. For him, such an inquiry entails an acutely active process for an independent mind, premised on faith in the human ability to improve matters. "The thinking that judges bring to bear in deciding issues of law is the sinew of law itself," he insists. ${ }^{6}$ Even if most judicial judgments, like other judgments, are "worked out backward from conclusions tentatively formulated,"7 it remains vital to consider institutional values "in a rational process of selecting from among competing legal principles and evolving new ones." 8

Judge Newman insists that we should recognize and think hard about a series of institutional values that inform much of what most judges actually do. These values include striving for sound predictions about future application; ease of comprehension; likely availability of necessary evidence; and the relative possibility of resisting manipulation or evasion by the shrewd or corrupt. Newman does not shrink from admitting that the institutional values he carefully elaborates have varying degrees of appropriateness within judicial decisions. ${ }^{9}$ In his judicial decisions as well as in his other writing, Newman demonstrates how vital it is to "rethink our conception of fairness not simply to save time and money but to distribute fairness more evenly." 10

Sadly today's aggressive Supreme Court interventionism operates in neglect of these insights. The Court differs in terms of such basics of judicial craftsmanship as candor and consistency; equal treatment of people and clear identification of cases that seem to be similarly situated; respect for the other branches of the federal government; and pragmatic consideration of the likely impact of the Court's decisions. During the Warren Court years, there was nothing comparable to today's fervor to cut the Gordian Knot and to let the pieces fall where they may-or to be swept off the board entirely, if a majority of the

6. Id. at 201 (1984) (Newman's footnote to this statement notes that his topic is worth pursuing only if judges are free to use their minds to make choices; and, he adds, "For me, it is sufficient simply to assert: I am, therefore I think." See id. at n.l.

7. Id. at $202, \mathbf{n} .2$.

8. Id. at 216.

9. Thus, for example, Newman contrasts appropriate literalism in interpreting the tax code with being more open to arguments based on legislative purpose in considering a civil rights act. Id. at 210 .

10. Jon O. Newman, Rethinking Faimess: Perspectives on the Litigation Process, 94 YALE L.J. 1643,1658 (1985). 
Justices does not approve of them. ${ }^{11}$ Even if we are accustomed to thinking about legal contests in terms of two sides, Judge Newman's ability to triangulate legal problems in new, clarifying ways affords an instructive contrast to the oversimplifications of today's prevalent worldview.

We will understand better the qualities we ought to seek in our federal judges if we briefly consider a sampling of Judge Newman's federal jurisdiction opinions, then turn to his proposed substantial reform of federal court jurisdiction, and finally examine his claims regarding an independent federal judiciary. Characteristically, Newman prods us to look to the future with thoughtful boldness, to consider all the chess moves way down the board. In the context of curbing the volume of federal court litigation, for example, he asserts that "adherence to the ways of the past is the surest prescription for inaction." 12 Paradoxically, radical reform is necessary to preserve an old and important value: "Federal courts should have at least the opportunity to adjudicate all issues of federal law." ${ }^{13}$

\section{Federal Courts Cases: A Small Sampler}

Perhaps because Jon Newman served with marked distinction in all three branches of the Federal government, and even more likely because federal courts' puzzles are so intriguingly intricate and yet of such considerable practical importance, he has been particularly drawn to issues relating to the jurisdiction of the federal courts. His teaching of the subject at the University of Connecticut School of Law is legendary. Lawyers delight to tell tales of his surefooted exploration of lurking issues and their implications that others may not even have begun to grasp. As his law clerks as well as lawyers and judges can attest, he often does this through questions that get directly to the nub of the matter in breathtakingly quick fashion. But Judge Newman also uses his own judicial opinions to probe, to suggest points of tension that others may not even have seen, and to propose solutions. A small sampler will serve to illustrate.

First, we might consider an obscure decision concerning a now virtually forgotten corner of federal court law that suggests the bold clarity of his reasoning. The issue in Coastal States Marketing $v$. New

11. Soifer, supra note 2, at 732-33.

12. Jon O. Newman, Restructuring Federal Jurisdiction: Proposals to Preserve the Federal Judicial System, 56 U. CHI. L. REv. 761, 774 (1989).

13. Id. at 777 . 
England Petroleum Corp ${ }^{14}$ involved violations of the federal price controls that were imposed during the Nixon Administration. Did the Temporary Emergency Court of Appeals (TECA), established by statute in 1970 and apparently granted exclusive jurisdiction by a 1971 statutory change, have jurisdiction? By the time Judge Newman had unpacked the boxes-within-boxes, it was clear that each of the three leading approaches that might anchor jurisdiction- "arising under" jurisdiction; case-specific jurisdiction; or issue-based jurisdiction - "implicates conflicting considerations." 15 Further, Newman observed for the Court, "statutory language offers clues but no firm answer," legislative history is "no aid," and "considerations of speed and consistency" actually point in opposite directions. ${ }^{16}$ (One can almost hear Newman's glee as he untangled the threads.) His innovative solution was to allow bifurcated federal appeals. Thus the TECA could hear some "issue" jurisdiction, without taking over an entire case from more standard federal court processes. The cogent self-confidence in Newman's map through the maze were striking, and his solution was quite innovative. Federal court judges, even those few who may be nearly as quick and clear as is Jon O. Newman, obviously need sufficient time to clarify such intricate issues carefully and to resolve such tangled disputes with wisdom extending beyond the customary reasoning by analogy.

Federal judges also should see enough diverse cases to be able to step outside somewhat and even to question. received wisdom. In an admiralty case, Peralta Shipping Corp. v. Smith $\mathcal{E}^{2}$ Johnson, ${ }^{17}$ for example, Judge Newman identified the "long-standing rule that suits upon general agency contracts are not within the jurisdiction of the silver oar." 18 Though he conceded that controlling precedent bound him, he nevertheless began to probe. He noted first that the rule barring admiralty jurisdiction was too broad. " $[\mathrm{A}] \mathrm{lmost}$ every general agency agreement can be said to involve 'necessary' services or some degree of supervi-

14. 604 F.2d 179 (1979). Judge Newman began the case as a District Court Judge sitting by designation, and moved to the Court of Appeals prior to decision. Judge Bonsal, who made up the panel along with Judge Van Graafeland, actually was also a member of the Temporary Emergency Court of Appeals, whose jurisdiction was partially at issue in the case. This was duly noted, and Bonsal concurred without comment.

15. Id. at 183 .

16. Id. at $183-34$.

17. 739 F.2d 798 (2d Cir. 1984), cert. denied, 470 U.S. 1031 (1985), rehearing denied, 471 U.S. 1112 (1985).

18. Id. at 799 . 
sion," ${ }^{19}$ he observed. (Within the decade, the Supreme Court agreed with Judge Newman and overruled the precedent whose wisdom he challenged in Peralta.) ${ }^{20}$ Boldly, Newman went further as he tartly noted: "Lack of subject matter jurisdiction has become the jurisprudential equivalent of the plague, requiring instant extirpation whenever noticed, even years after adjudication . . . to safeguard the purity of judicial processes from this most dreaded form of contamination."21 "[S]peaking only for himself," he wrote, he even dared to wonder "whether such unquestioning condemnation of judgments entered by courts without subject matter jurisdiction is always warranted."22

In one decision, for example, Judge Newman questioned the hoary Mottley rule and its accompanying "esoteric doctrine of 'artful pleading." "23 In another, he determined that federal common law is not exclusive in resolving a contract dispute containing an international legal element. ${ }^{24}$ Judge Newman also wrestled at length with the "jurisdictional conundrum" of how a treaty with the Oneida Indian Nation under the Articles of Confederation ought to fit within the subsequent U.S. Constitution's jurisdictional provisions. ${ }^{25}$ When he upheld federal court jurisdiction in a civil suit seeking remedies for atrocities committed in Bosnia, Newman's Second Circuit opinion rejected a state action requirement for imposing the law of nations and went on to find the atrocities claim justiciable. Newman read the Alien Tort Act broadly and declined to create federal common law immunity for Kadiev Karadzic. Karadzic could find himself within federal court jurisdiction because-though he apparently had come to New York for United Nations business-he was not in transit, did not have official

19. Id. at 804 .

20. The Court did so in an opinion written by Justice Marshall in Exxon Corp. v. Central Gulf Lines, 500 U.S. 603 (1991), overruling Minturn v. Maynard, 58 U.S. (17 How.) 477 (1855).

21. Peralta Shipping Corp., 739 F.2d at 804 n.6.

22. Id.

23. Travelers Indemnity Co. v. Sarkisian, 794 F.2d 754, 754 (2d Cir.), cert. denied, 479 U.S. 885 (1986) (asking why preemption is not limited to a defense, rather than serving as a ground for removal to federal court).

24. Nordlicht v. New York Tel. Co., 799 F. 2d 859 (2d Cir. 1986), cert. denied, 479 U.S. 1055 (1987) (noting that the need for uniformity in the application of federal legal standards is not alone a sufficient basis for federal courts to determine that their jurisdiction is exclusive). Characteristically, Newman also discovered a typo within the statutory reference the Court was construing. Id. at n.4.

25. Oneida Indian Nation of New York v. State of New York, 860 F.2d 1145, 115960 (2d Cir. 1988). 
diplomatic immunity, and had traveled beyond the headquarters district of the United Nations itself.

To discern paths through the law such as these consistently requires independence of spirit and almost uncanny clarity of thought. Few (if any) judges are Newman's equal in setting out clearly what competing positions entail and why a hitherto unseen third way might well be preferable. His rare combination of sophisticated legal insight, wordsmithery, and intellectual boldness is a powerful reminder of what we expect a good, or even a great, judge to do.

\section{Restructuring Federal Jurisdiction}

Even though there are only two sides to a paradigmatic legal contest, Newman has an uncanny ability to triangulate a legal problem in new, clarifying ways. This is not only as he handles cases, but also as he suggests reforming legal institutions. In considering the appropriate role for federal courts, and for federal judges, one should begin by conceding that it simply is not fair to extrapolate much from Judge Newman. This is not only because he is exceptionally hard working and unusually smart. He is also simply and easily the best lawyer whom I (along with many others) ever met. The clarity of this observation is anchored within his uncanny quickness in getting directly to the specific essence of any legal issue, and his remarkable, balanced, and keenly practical sense of the implications of any decision.

As he analyzes a problem, Newman's ability to cut through to the essence contrasts sharply with the abstract, untethered essentialism that is currently much in vogue in matters of federalism. His insistent practicality does not overlap much with the self-proclaimed pragmatism of another well-known contemporary appellate judge, Richard Posner. Though Posner somehow manages to write significant books more or less on a weekly basis, many of those books and some of his judicial decisions suggest that his particular brand of pragmatism sometimes moves close to solipsism and cynicism. By contrast, Newman's analytic pragmatism refuses to rely upon some Platonic ideal of an overarching single principle.

In fact, Judge Newman's approach considers both the facts and the law to be composed of interlocking, often changing moveable parts. Yet he regards neither category as entirely indeterminate. Nor will he let any pre-arranged agenda or simple binary choice carry the analytic load. Instead, he seeks to grasp the specifics and to think hard about how they relate to more general issues. This is an acutely active 
process for an independent mind. It is ironic, he points out, "that the medical profession has made enormous progress by experimentation with matters of life and death, while we in the law shun experimental ways of deciding matters of property." 26 The task of getting close to the essence, as well as the duty to be practical, also involves deep faith in the human ability to improve things, including law and legal institutions.

Newman's proposals to alter federal court jurisdiction, and to do so substantially, ought to be taken quite seriously on their merits. They also illustrate his point that significant improvements are possible only if we somehow manage to escape the fateful attraction of easy binary categories. To Newman, our central image ought not to be state courts versus federal courts. Instead, he proposes an intertwined model. He convincingly argues that unless his proposal, or some other substantial retooling, is soon achieved, the federal courts as we have known them will be overwhelmed and eviscerated.

Newman makes a persuasive argument in favor of an elite, as well as a boldly independent, federal court model. Character, time, and skill are all required to perform as judges within "a relatively small, specialized institution of distinction." 27 Collegiality is also necessary. An appellate court with too many judges, for example, soon is transformed into "a stable of judges, each one called upon to plough through the unrelenting volume, harnessed on any given day with two other judges who hardly know each other." 28 Moreover, Newman asserts, there is "an immutable fact of government life: judges are added at a rate that always falls far short of the rate of increase in case volume." 29

So, what is to be done?

First, Newman explains, we need a dose of realism about the massive explosion of cases, laws, and lawyers. This ought to be followed by using our imagination. Indeed, "In the search for ways to curb the volume of federal court litigation, adherence to the ways of the past is the surest prescription for inaction." ${ }^{30}$ Next, he calls for rethinking the relationship between federal and state courts. They ought not to

26. Newman, supra note 10 , at 1659 .

27. Jon O, Newman, 1,000 Judges-the Limit for an Effective Federal Judiciary, 76 JUDICATURE 187 (1993).

28. Id. at 188 .

29. Id. at 193 .

30. Newman, supra note 12 , at 774 . 
be viewed as binary systems, but rather as intricately intertwined systems replete with a myriad of discretionary, gate-keeping calls. Moreover, we ought to recognize that the current system undermines many of the goals we have identified as primary. Thus, for example: (1) current diversity jurisdiction actually keeps state judges from being final arbiters of state law; and (2) current rules precluding federal defenses as a ground for federal jurisdiction actually operate to preclude federal courts from being final arbiters of federal law. ${ }^{31}$

In perceiving the two court systems as intertwined, Newman argues that reform efforts need not change entire categories of cases, nor should they regard either system as the exclusive entry point for particular kinds of cases. Indeed: some kinds of cases need not have exclusive resolution within either system. Among the fundamental changes he proposes are:

1. Allowing discretion in federal courts as to which cases to keep and which to send to state court, without requiring any finding that the state system is in any way inadequate;

2. Leaving such discretionary decisions in the hands of federal court of appeals judges, who will make their discretionary calls without fact-finding and with no appeal available;

3. Allowing appeals of cases - at least appeals of some issues such as federal law matters-to go back and forth between the two systems without any clear hierarchy between them.

Always fond of data, Newman points out; for example, that a transfer of some 70,000 civil cases of the federal court total of 240,000 in 1988 would reduce the federal court caseload by 30 percent, while it would only increase the state court caseload by one percent. ${ }^{32}$ He also makes a case for the increasing problem of less care and less quality in the selection of federal judges as their numbers escalate, in part based on how many congressional days are already consumed in the nomination and confirmation process.

31. Id. at 776-77.

32. Id. at 769 (footnotes omitted). Newman identifies as likely candidates for discretionary access to federal courts some categories of cases, such as FELA and Jones Act cases that are already heard in large numbers in state courts, as well as diversity cases brought by in-state plaintiffs. Id. at 771 . 
One strong counter-example to Newman's proposal, however, can also be anchored in numbers. The current Supreme Court has been taking a much-reduced number of cases as compared to its docket several decades ago. ${ }^{33}$ Yet that reduction in numbers hardly has seemed to aid the Court in its collegiality or in the quality of its work. Moreover, federal law is itself in, or is at least fast approaching, a state of disarray. ${ }^{34}$ Finally, as a practical matter, it is difficult to discern how to convince anyone to change the existing system. Reform may be particularly difficult among judges and lawyers, but currently it seems nearly impossible to pinpoint anyone inclined to implement such far-reaching change, even if only on an experimental basis. Congress clearly seems to lack the attention span and appetite for nuance needed to protect the federal courts and to help them meet the practical crisis they now confront.

Still, with their lifetime appointments, federal judges should be different and more independent. Accountability almost surely has been oversold substantially in the course of our recent federalism debates. ${ }^{35}$ Can even a highly informed citizen keep track of government funding, for example, to be able to sort out federal funding from state funding in an era of intertwined government programs? (We've even been reminded recently that accountants can be grievously unaccountable). Do most Americans know the identity of their state representatives or senators, let alone where these elected officials stand on the pressing issues of the day? States' rights still seems to serve as a code for uncritical defaulting to the local powers that be; the federal government is once again a handy bogeyman-until its resources are needed. For all that, the largely unaccountable nature of federal judges ought to prompt close attention to how a federal judge defines and plays his or her judicial role.

33. During the Court's 1999 Term, for example, the total of 76 plenary review decisions was the lowest in a half century, and less than half the number of plenary decisions during the 1972 Term. Margaret Meriwether Cordray \& Richard Cordray, The Supreme Court's Plenary Docket, 58 WAsH. \& LeE L. Rev. 737 (2001).

34. This includes increased vitriol and even outright name-calling among judges; battles over timing and decisions to go en banc; struggles between the Supreme Court and certain Circuits (while others can almost reliably be counted on to provide a split on the law so that the Supreme Court comfortably can grant certiorari if it wishes to do so, and so forth. With a perspective far different from that of the current Supreme Court majority, Newman observes: "The origin of the states, the formation of the Union, the adoption of the Constitution, the Civil War, the Reconstruction Amendments, the realities of national power in post-New Deal America-in short, all of our history and all of our practice limit the range within which a judge is entitled to have views about federalism." Newman, supra note 3, at 211.

35. See, e.g., Printz v. United States, 521 U.S. 898 (1997); New York v. United States, 505 U.S. 144 (1992). 


\section{The Federal Judicial Role}

Boldness in the service of equitable results-not mainly through passion, but rather through the cool ability to reason-is a rarity anywhere. It entails a hard-won philosophic stance and an ability to think hard about the future as well as to understand the past. For Newman, at least, such bold thinking is grounded in a sense of law and, particularly, of litigation as a complex entity, sometimes mechanical but much more often organic, sporting multiple changing, moveable parts. And, as Newman reminds us, "Those who care about the development of law concern themselves at least as much with the judge's thinking as with the judge's result." 36 In the current federal judicial climate, however, this strong focus on thinking as well as on results sadly seems increasingly quaint.

It is also rare to find judges willing to admit publicly that "legal principles reflect the untidiness of life" 37 and to point out that the content of the relevant competing principles in a close case is never static. It is rarer still to come across judges who concede that "[e]very judge approaches decision making with a value-laden view of the role of courts," 38 and who still go on to explore both the limitations and the possibilities for changing the inductive process, used by most judges to decide most cases.

As a young Hartford lawyer forty years ago, Newman wrote an essay marking Justice Felix Frankfurter's retirement. In his graceful tribute, Newman proclaimed Frankfurter to be "not replaceable," and went on to defend Frankfurter against his many critics who claimed that the formerly liberal activist had "changed his mind" when he became a Justice. ${ }^{39}$ Newman acknowledged that there had been change. "But," he added, "it was not the man's viewpoint that changed, it was his job." 40 Tellingly, Newman went on to emphasize Frankfurter's belief "that a judge must exercise limited power, especially when faced with the most monumental question that ever comes before the nation's highest tribunal: does an act of Congress, signed into law by the president, violate the U.S. Constitution?" 41 (Would that the current Court thought that second-guessing federal legislation was a somewhat deli-

36. Newman, supra note 3, at 200.

37. Id. at 208. See also Jon O. Newman, Ode to the Guidelines, 9 F.SENT.R 338 (1997).

38. Newman, supra note 3, at 208.

39. Jon O. Newman, Mr. Justice Frankfurter, 36 Conn. Bar Journal 527 (1962).

40. Id. at 528 (emphasis in original).

41. Id 
cate matter, to say nothing of being "the most monumental question." ${ }^{42}$ The point, said Newman, concerned democratic process. "Or put another way, in a democracy, one of the people's basic rights is the right to make dreadful mistakes." 43

Even more telling, however, was an important further point: Newman criticized Frankfurter and his supporters for claiming that only Frankfurter's position was disinterested-and that those Justices who disagreed with him were merely giving vent to personal whims and prejudices. To illustrate, Newman invoked Trop $v$. Dulles, ${ }^{44}$ handed down during the year Newman clerked on the Supreme Court. To this day, I have never asked nor heard about what if any role Newman might have played as a law clerk in this case. ${ }^{45}$ In Trop v. Dulles, Chief Justice Warren's plurality opinion held that the military could not constitutionally strip citizenship from a soldier who had been court-martialed and dishonorably discharged for desertion in time of war. Trop had escaped from the military stockade in Casablanca in 1944. He was picked up the following day while on his way back, apparently having changed his mind. Warren wrote, "Courts must not consider the wisdom of statutes but neither can they sanction as being merely unwise that which the Constitution forbids." 46 This Eighth Amendment holding-and the startling number of other decisions during the 1957 Term that dealt with matters of deportation, loyalty, and guilt by association-seem all too freshly relevant today. Yet one is also struck by how far we have moved from that era's more common recognition that even when judges disagree, adjudication still entails "a judgment

42. A good recent example of the difference in tone as well as in thinking and results is Justice Scalia's sarcastic statement about Congress as the Court imposed state immunity in College Savings Bank v. Florida Prepaid Postsecondary Educ. Expense Bd., 527 U.S. 666, 690 (1999): "Legislative flexibility on the part of Congress will be the touchstone of federalism when the capacity to support combustion becomes the acid test of a fire extinguisher."

43. Newman, supra note 39 , at 529 .

44. 356 U.S. 86 (1958) (Newman, the printer, or someone else miscited Trop. This is a commonplace occurrence, of course, but it seems amazing to those who know Newman's meticulous attention to detail in matters ranging from his discovery of two different versions of early U.S. Reports, Jon O. Newman, Citators Beware: Stylistic Variations in Different Publishers' Versions of Early Supreme Court Opinions, 26 S. Cr. Hist. Soc. 1 (2001) to his forthcoming book, A Genealogical Chart of Greek Mythology (co-compiled with his late father) to be published in June, 2003 by the University of North Carolina Press).

45. Most law clerks seem to play larger roles than do Newman's clerks. Other judges tend to be not nearly so hard working, quick, careful, and able to churn out almost nearly perfect first drafts.

46. 356 U.S. at 103 . 
resolving a very complex question" in which "the intellectual process" matters, as well as the "results." 47 Key to that process is the ability of judges to think fearlessly for themselves even as they tolerate the views of others.

Newman actually has enacted this quality-this combination of intellect and courage-in defense of the very quality itself. One thinks, for example, of his public intervention (joined by three former Chief Judges of the Second Circuit) against the attacks on Judge Baer by both President Clinton and his opponent Senator Dole during the 1996 presidential campaign. Noting the constraints of the Code of Conduct, Newman anchored his letter in the affirmative duty imposed on federal judges to "uphold the integrity and independence of the judiciary." 48 But I also have in mind his still braver New York Times Op Ed piece concerning the nomination of Clarence Thomas, before the bigger scandal broke. ${ }^{49}$ There are many constraints, but judges also have affirmative duties.

Quite simply and quite brilliantly, Jon Newman exemplifies how to "uphold the integrity and independence of the judiciary." Published comments from lawyers evaluating Newman as a judge are full of superlatives as they describe his legal abilities, his preparation, his courtesy to lawyers, his balance, and his opinions. His scary smartness, bold intellect, and keen practical sense are obvious. Paradoxically, however, it is a combination of the parties before him and his law clerks-those in the courtroom who are among the most detached and those who are the most attached-who recognize that Newman also knows how to engage and even to listen. He is keenly concerned with fairness, after all, both systemically and in all the particulars.

It is fitting that we try to follow him in thinking boldly. Once before I mentioned that to think about Judge Newman's role as a judge brings to mind an idea in the Talmud: "to judge with complete fairness for even a single hour" is to be credited as though one has become a partner with God in the work of creation. ${ }^{50}$ At first and even second glance, the Talmudic tradition and Jon Newman do not seem to be closely in synch. Yet after learning a little Talmud, as well as

47. Newman, supra note 39 , at 531-32 (emphasis in original).

48. Jon O. Newman, The Judge Baer Controversy, 80 Judicature 156, 159 (1997).

49. Jon O. Newman, A Replacement for Thomas, N.Y. Times, Oct. 10, 1991, at § A 27.

50. Proceedings, Presentation of Portrait, Honorable Jon O. Newman, Senior Circuit Judge, United States Court of Appeals for the Second Circuit, October 8, 1998, 175 F.3d lxi, lxxx. 
reviewing a little of what Newman has been saying and doing during these remarkable thirty years, I am even more convinced of the aptness of the analogy. What a partnership! Judge Newman's sense of engaged, open-ended dialogue takes law very seriously across its changing dimensions. His remarkable enthusiasm to dig out the facts and to ask tough questions-and constantly to challenge what has come before without trying to topple it-embodies an ideal of the fair judge. It is this type of independent, thoughtful, questing judge that (or is it which? $)^{51}$ we aspire to find across many years and multiple cultures.

The federal courts did not make Newman what he is, nor can we think of many others within the federal courts who are within range of his talents and accomplishments. But if the likes of Jon Newman can remain happily engaged in these federal courts, this fact alone indicates that this institution still embodies fundamentally important values that richly deserve and require our attention-as well as much more bold, constructive Newmanescent thought.

51. In contrast to the enthusiasm warmly expressed by most of Newman's law clerks at a clerks' reunion dinner, one clerk described how intimidating he had found it to be to work for the Judge. It is widely known that Newman is an enthusiast about appropriate language usage. (He has been quoted several times in William Safire's New York Times Sunday Magazine column, On Language, for example, and in 1998 he discussed his neologism, "polycronym" in "Word Words," published in Verbatim, a language magazine). Steven Ecker related that, at the start of his clerkship, he got a draft back pointing out that he had mixed up "that" and "which." Ecker claimed that the rest of the year was quite difficult because he could not understand the rule-and he found it excruciating to avoid using both "that" and "which" for an entire year. 